STATE OF ALASKA

DEPARTMENT OF NATURAL RESOURCES

Alaska Geologic Materials Center Data Report No. 413

\title{
No. 413
}

Gottlieb, E., 2012, LaserChron (Nu Instruments HR ICP Mass Spectrometer) data of Triassic and Carboniferous outcrop samples from the Karen Creek, Ivishak, and Nuka Formations, Western and Eastern Brooks Range, Alaska

Zip file available for download

Received October 2012

All data reports may be downloaded free of charge from the DGGS website. 